\title{
Callyaerin G, a new cytotoxic cyclic peptide from the marine sponge Callyspongia aerizusa
}

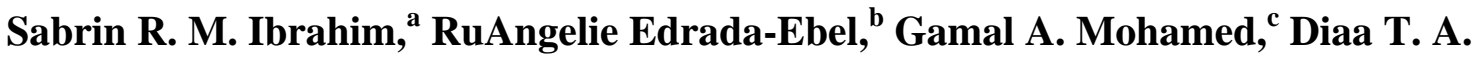 \\ Youssef, ${ }^{\mathrm{d}}$ Victor Wray, ${ }^{\mathrm{e}}$ and Peter Proksch*,f
}

${ }^{a}$ Pharmacognosy Department, Faculty of Pharmacy, Assiut University, Assiut 71526, Egypt

${ }^{b}$ Strathclyde Institute of Pharmacy and Biomedical Science, University of Strathclyde, The John

Arbuthnott Building, 27 Taylor Street, Glasgow G4 ONR, United Kingdom

${ }^{c}$ Pharmacognosy Department, Faculty of Pharmacy, Al-Azhar University, Assiut branch, Assiut 71524, Egypt

${ }^{d}$ Department of Pharmacognosy, Faculty of Pharmacy, Suez Canal University, Ismailia 41522,

Egypt

${ }^{e}$ Helmholtz Centre for Infection Research, Inhoffenstrasse 7, 38124 Braunschweig, Germany

${ }^{f}$ Institute für Pharmazeutische Biologie und Biotechnologie, Heinrich-Heine Universität,

Universitätsstrasse 1, Geb. 26.23, D-40225 Düsseldorf, Germany

E-mail:proksch@uni-duesseldorf.de

\begin{abstract}
From the ethyl acetate fraction of the Indonesian sponge Callyspongia aerizusa extract, a new cyclic peptide named callyaerin $\mathrm{G}$ was isolated. Its structure was elucidated by extensive $1 \mathrm{D}$ and 2D NMR (1H NMR, TOCSY and ROESY) studies and mass spectrometric data (ESI- and FABMS). The stereochemistry was determined by Marfey`s analysis. Callyaerin G was found to exhibit cytotoxic activity when tested against different cancer cell lines.
\end{abstract}

Keywords: Callyspongia aerizusa, Callyaerin G, Marfey's analysis, cytotoxicity

\section{Introduction}

Sponges belonging to the genus Callyspongia have been reported to yield unusual secondary metabolites with pronounced biological activities. Examples of these secondary metabolites are polyacetylenic compounds with different chain lengths, ${ }^{1-5}$ depsipeptides, ${ }^{6}$ and cyclic peptides. ${ }^{7, a, b}$ Our ongoing research for biologically active metabolites from marine organisms led to the isolation of a new cyclic peptide from the Indonesian sponge Callyspongia aerizusa, for which we propose the name callyaerin G. In this paper, we describe the isolation and structural elucidation of this new cyclic peptide, together with its cytotoxic activity. 


\section{Results and Discussion}

The ethyl acetate fraction of the freeze-dried sponge Callyspongia aerizusa afforded a new cyclic peptide with potent cytotoxic activity. This compound was obtained as an optically active, white amorphous powder. The FAB- and (+) ESI-MS spectra showed pseudomolecular ion peaks at $\mathrm{m} / \mathrm{z} 1294[\mathrm{M}+\mathrm{H}]^{+}$and $1316[\mathrm{M}+\mathrm{Na}]^{+}$, which were consistent with molecular formula $\mathrm{C}_{69} \mathrm{H}_{91} \mathrm{~N}_{13} \mathrm{O}_{12}$ confirmed by HRESIMS. This requires 30 double bond equivalents (DBE). The peptide has UV absorbance at $\lambda_{\max } 207$ and $285 \mathrm{~nm}$ and the IR spectrum showed absorption bands at $\gamma_{\max }(\mathrm{KBr}) 3340(\mathrm{OH}), 1665$ (amide) and $1535(\mathrm{C}=\mathrm{C}) \mathrm{cm}-1$. The peptide nature was evident from the 1H NMR spectrum (Table 1), which showed numerous deshielded amide NH resonances and a cluster of $\alpha$-amino acid methines. Interpretation of the TOCSY spectrum revealed the presence of eleven spin systems which could be assigned to eleven amino acid residues [1 Gly, 3 Phe, 2 Leu and 5 Pro]. Uncommon signals at $\delta_{\mathrm{H}} 8.23(\mathrm{~s}, \mathrm{NH})$ and $7.46(\mathrm{~d}, \mathrm{~J}=$ 13.6 Hz, H- $\beta$ ) in ${ }^{1} \mathrm{H}$ NMR were assigned to FGly 7 (formylglycine). 7 In addition, two singlet signals were observed at $\delta_{\mathrm{H}} 7.11$ (brs) and 7.12 (brs) attributed to a terminal $\mathrm{NH}_{2}$-group. ${ }^{8 \mathrm{a}, \mathrm{b}}$

The amino acids sequence, position of the terminal $\mathrm{NH}_{2}$ and the cyclic nature of the isolated compound were deduced by interpretation of its ROESY spectra (Figure 2). The terminal $\mathrm{NH}_{2}$ showed ROESY correlations to Phe 12-NH, Phe 12- $\alpha \mathrm{H}$ and Phe 12- $\beta \mathrm{H}$, which established the attachment of NH2 to Phe-12. Phe 12-NH showed cross peaks to Phe 11-NH and Phe 11- $\alpha \mathrm{H}$ which connected Phe 12 to Phe 11 [substructure A]. Gly 10, Phe 9 and Pro 8 were linked to give the tri-peptide substructure B. This was justified by the ROESY correlations of Gly 10-NH, Pro $8-\alpha \mathrm{H}$ to Phe $9-\mathrm{NH}$ and Phe $9-\alpha \mathrm{H}$, Phe $9-\beta \mathrm{H}$ to Pro $8-\alpha \mathrm{H}$. The connectivity of substructure A and B was confirmed by the ROESY correlations of Phe 11-NH to Gly 10-NH and Gly $10-\alpha \mathrm{H}$ and Phe $11-\alpha \mathrm{H}$ to Gly $10-\alpha \mathrm{H}$. These two substructures constitute a linear pentapeptide side chain. The ESI- and FAB-MS spectra, which gave a fragment ion peak at $\mathrm{m} / \mathrm{z} 682$ for $[\mathrm{M}-(\mathrm{NH} 2+\text { Phe } 12+\text { Phe } 11+\text { Gly } 10+\text { Phe } 9+\text { Pro } 8)]^{+}$provided further confirmation of the AB substructure. The FGly 7-NH ROESY correlation to Leu 1-NH and FGly 7- $\beta \mathrm{H}$ to Leu 1- $\alpha \mathrm{H}$ and Leu 1- $\beta \mathrm{H}$ assigned the amide linkage of FGly 7 to Leu 1 to give substructure C. Pro-2, Pro-3 and Pro-4 were linked to give tri-peptide substructure D, which was proven by the ROESY correlations of Pro 2- $\alpha \mathrm{H}$ and Pro 2- $\beta \mathrm{H}$ to Pro 3- $\delta \mathrm{H}$ and Pro 3- $\alpha \mathrm{H}$ to Pro $4-\alpha \mathrm{H}$. The amide linkage between substructures $\mathrm{C}$ and D was confirmed by the cross peaks between Leu 1-NH and Leu 1$\alpha \mathrm{H}$ to Pro 2- $\alpha \mathrm{H}$ and Pro 2- $\delta \mathrm{H}$ to Leu 1- $\alpha \mathrm{H}$. Pro 5- $\alpha \mathrm{H}$ and Pro 5- $\beta \mathrm{H}$ showed correlations to Leu 6-NH, as well as Leu 6- $\alpha \mathrm{H}$ to Pro 5- $\alpha \mathrm{H}$ [substructure E]. Substructures D and E were connected through the observed ROESY correlations of Pro 4- $\alpha \mathrm{H}$ to Pro 5- $\alpha \mathrm{H}$. ROESY correlations of FGly 7-NH to Leu 6-NH and Leu 6- $\alpha \mathrm{H}$ established the cyclization via amide bond formed between FGly 7 and Leu 6 . The attachment of the cyclic peptide part to the linear peptide chain was confirmed by the ROESY correlations of FGly 7-NH to Pro $8-\delta H$.

Comparison of the NMR data and molecular weight of the isolated compound with those of the previously reported callyaerins from Callyspongia aerizusa ${ }^{8 \mathrm{a}, \mathrm{b}}$ in combination with a careful inspection of the ${ }^{1} \mathrm{H}$ NMR, TOCSY and ROESY spectra allowed the complete assignment of all signals to this new natural product which we assign the name callyaerin $G$, a cyclic peptide linked to linear peptide side chain through an $\alpha$-amido- $\beta$-aminoacrylamide 
functional group. ${ }^{7}$ This is formed by the condensation of the aldehyde group of formyl glycine (FGly) and the amino group of Leu 1 to give a conjugated acrylamide function through carbinol amine directly or isomerization of a Schiff base. ${ }^{9}$ This functional group in a peptide has to date only been described from the sponge of the genus Callyspongia. ${ }^{7,8 a, b}$ To the best of our knowledge this is the first report of a peptide containing a terminal $\mathrm{NH}_{2}{ }^{8 \mathrm{a}, \mathrm{b}}$

The stereochemistry of the individual amino acid constituents of callyaerin $\mathrm{G}$ was determined by acid hydrolysis of the parent peptide and consequent derivatization using Marfey's analysis. ${ }^{10}$ Stereochemical assignments were made using LC-MS technique to compare the amino acids of this peptide with appropriate standards. The LC-MS analysis of the resulting (N-(5-fluoro-2,4dinitrophenyl)-L-leucinamide) derivatives led to the assignment of $\mathrm{L}$ configuration of all amino acid residues. Callyaerin $\mathrm{G}$ was found to be cytotoxic towards the mouse lymphoma cell line (L5178Y) and HeLa cells with ED50(s) of 0.53 and $5.4 \mathrm{ug} / \mathrm{mL}$, respectively, while it was found to be inactive against PC12.

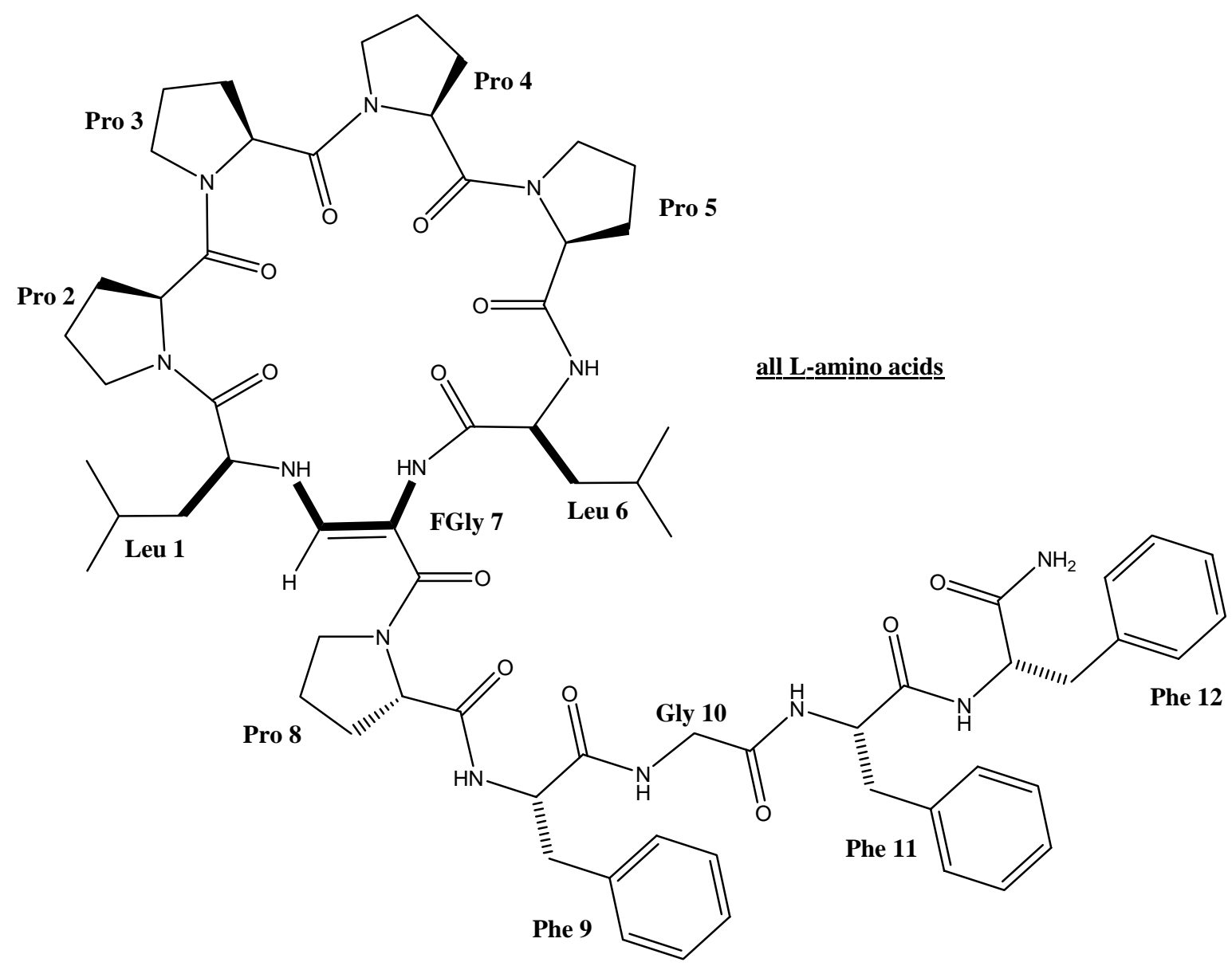

Figure 1. Structure of the isolated peptide. 
Table 1. ${ }^{1} \mathrm{H}$ NMR data of the isolated compound (DMSO-d6, $600 \mathrm{MHz}$ )

\begin{tabular}{|c|c|c|c|}
\hline Amino acid & Proton & $\delta_{\mathrm{H}}(\mathrm{J} \mathrm{Hz}, \mathrm{m})$ & ROESY \\
\hline \multirow[t]{6}{*}{ Leu $^{1}$} & $\alpha$ & $4.22,1 \mathrm{H}, \mathrm{m}$ & $2-\alpha, 7-\beta$ \\
\hline & $\beta$ & $1.62,2 \mathrm{H}, \mathrm{m}$ & \\
\hline & $\gamma$ & $1.33,1 \mathrm{H}, \mathrm{m}$ & \\
\hline & $\delta$ & $0.53,3 \mathrm{H}, \mathrm{d}, \mathrm{J}=6.8 \mathrm{~Hz}$ & \\
\hline & $\delta^{\prime}$ & $0.38,3 \mathrm{H}, \mathrm{d}, \mathrm{J}=6.8 \mathrm{~Hz}$ & \\
\hline & $\mathrm{NH}$ & $5.32,1 \mathrm{H}, \mathrm{d}, \mathrm{J}=7.3 \mathrm{~Hz}$ & $2-\alpha, 7-\mathrm{NH}$ \\
\hline \multirow[t]{5}{*}{$\mathrm{Pro}^{2}$} & $\alpha$ & $4.41,1 \mathrm{H}, \mathrm{dd}, \mathrm{J}=9.8,7.9 \mathrm{~Hz}$ & $1-\mathrm{NH}, 1-\alpha, 3-\alpha, 3-\delta$ \\
\hline & $\beta$ & $1.94,1 \mathrm{H}, \mathrm{m}$ & $3-\delta$ \\
\hline & $\gamma$ & $\begin{array}{l}1.83,1 \mathrm{H}, \mathrm{m} \\
2.15,2 \mathrm{H}, \mathrm{m}\end{array}$ & \\
\hline & $\delta$ & $3.45,1 \mathrm{H}, \mathrm{m}$ & $1-\alpha$ \\
\hline & & $3.38,1 \mathrm{H}, \mathrm{m}$ & \\
\hline \multirow[t]{7}{*}{$\mathrm{Pro}^{3}$} & $\alpha$ & $4.34,1 \mathrm{H}, \mathrm{dd}, \mathrm{J}=11.3,7.2 \mathrm{~Hz}$ & $2-\alpha, 4-\alpha$ \\
\hline & $\beta$ & $1.80,1 \mathrm{H}, \mathrm{m}$ & \\
\hline & & $1.78,1 \mathrm{H}, \mathrm{m}$ & \\
\hline & $\gamma$ & $2.08,1 \mathrm{H}, \mathrm{m}$ & \\
\hline & & $1.93,1 \mathrm{H}, \mathrm{m}$ & \\
\hline & $\delta$ & $3.86,1 \mathrm{H}, \mathrm{m}$ & $2-\alpha$ \\
\hline & & $3.36,1 \mathrm{H}, \mathrm{m}$ & \\
\hline \multirow[t]{7}{*}{$\mathrm{Pro}^{4}$} & $\alpha$ & $3.92,1 \mathrm{H}, \mathrm{m}$ & $3-\alpha, 5-\alpha, 5-\delta$ \\
\hline & $\beta$ & $1.88,1 \mathrm{H}, \mathrm{m}$ & \\
\hline & & $1.62,1 \mathrm{H}, \mathrm{m}$ & \\
\hline & $\gamma$ & $2.12,1 \mathrm{H}, \mathrm{m}$ & \\
\hline & & $2.01,1 \mathrm{H}, \mathrm{m}$ & \\
\hline & $\delta$ & $3.49,1 \mathrm{H}, \mathrm{m}$ & \\
\hline & & $3.40,1 \mathrm{H}, \mathrm{m}$ & \\
\hline \multirow[t]{7}{*}{$\mathrm{Pro}^{5}$} & $\alpha$ & $4.23,1 \mathrm{H}, \mathrm{m}$ & $4-\alpha, 6-\mathrm{NH}$ \\
\hline & $\beta$ & $1.67,1 \mathrm{H}, \mathrm{m}$ & $6-\mathrm{NH}$ \\
\hline & & $1.46,1 \mathrm{H}, \mathrm{m}$ & \\
\hline & $\gamma$ & $2.27,1 \mathrm{H}, \mathrm{m}$ & \\
\hline & & $1.78,1 \mathrm{H}, \mathrm{m}$ & \\
\hline & $\delta$ & $3.41,1 \mathrm{H}, \mathrm{m}$ & \\
\hline & & $2.75,1 \mathrm{H}, \mathrm{m}$ & \\
\hline \multirow[t]{6}{*}{$\mathrm{Leu}^{6}$} & $\alpha$ & $4.46,1 \mathrm{H}, \mathrm{dt}, \mathrm{J}=10.0,3.8 \mathrm{~Hz}$ & $5-\alpha, 7-\mathrm{NH}$ \\
\hline & $\beta$ & $1.92,2 \mathrm{H}, \mathrm{m}$ & \\
\hline & $\gamma$ & $1.75,1 \mathrm{H}, \mathrm{m}$ & \\
\hline & $\delta$ & $0.86,3 \mathrm{H}, \mathrm{d}, \mathrm{J}=6.7 \mathrm{~Hz}$ & \\
\hline & $\delta^{\prime}$ & $0.82,3 \mathrm{H}, \mathrm{d}, \mathrm{J}=6.7 \mathrm{~Hz}$ & \\
\hline & $\mathrm{NH}$ & $7.51,1 \mathrm{H}, \mathrm{d}, \mathrm{J}=9.4 \mathrm{~Hz}$ & $5-\alpha, 5-\beta, 7-\mathrm{NH}$ \\
\hline
\end{tabular}


Table 1. Continued

\begin{tabular}{|c|c|c|c|}
\hline Amino acid & Proton & $\delta \mathrm{H}(\mathrm{J} \mathrm{Hz}, \mathrm{m})$ & ROESY \\
\hline \multirow[t]{2}{*}{ FGly $^{7}$} & $\beta$ & $7.46,1 \mathrm{H}, \mathrm{d}, \mathrm{J}=13.6 \mathrm{~Hz}$ & $1-\alpha, 1-\beta$ \\
\hline & $\mathrm{NH}$ & $8.23,1 \mathrm{H}, \mathrm{s}$ & $1-\mathrm{NH}, 6-\mathrm{NH}, 6-\alpha, 8-\delta$ \\
\hline \multirow[t]{6}{*}{ Pro $^{8}$} & $\alpha$ & $4.11,1 \mathrm{H}, \mathrm{dd}, \mathrm{J}=10.0,7.5 \mathrm{~Hz}$ & $9-\alpha, 9-\mathrm{NH}$ \\
\hline & $\beta$ & $1.69,1 \mathrm{H}, \mathrm{m}$ & \\
\hline & & $1.06,1 \mathrm{H}, \mathrm{m}$ & \\
\hline & $\gamma$ & $1.90,2 \mathrm{H}, \mathrm{m}$ & \\
\hline & $\delta$ & $3.83,1 \mathrm{H}, \mathrm{m}$ & \\
\hline & & $3.37,1 \mathrm{H}, \mathrm{m}$ & \\
\hline \multirow[t]{5}{*}{$\mathrm{Phe}^{9}$} & $\alpha$ & $4.25,1 \mathrm{H}, \mathrm{m}$ & $8-\alpha, 10-\mathrm{NH}$ \\
\hline & $\beta$ & $2.92,1 \mathrm{H}, \mathrm{dd}, \mathrm{J}=13.1,8.5 \mathrm{~Hz}$ & $8-\alpha$ \\
\hline & & $2.45,1 \mathrm{H}, \mathrm{dd}, \mathrm{J}=13.1,8.5 \mathrm{~Hz}$ & \\
\hline & $\mathrm{NH}$ & $7.67,1 \mathrm{H}, \mathrm{d}, \mathrm{J}=8.8 \mathrm{~Hz}$ & $8-\alpha, 10-\mathrm{NH}$ \\
\hline & aromatic & $7.26-7.15$ & \\
\hline \multirow[t]{3}{*}{ Gly $^{10}$} & $\alpha$ & $3.91,1 \mathrm{H}, \mathrm{dd}, \mathrm{J}=16.5,5.0 \mathrm{~Hz}$ & $11-\alpha, 11-\mathrm{NH}$ \\
\hline & & $3.41,1 \mathrm{H}, \mathrm{dd}, \mathrm{J}=16.5,5.0 \mathrm{~Hz}$ & \\
\hline & $\mathrm{NH}$ & $7.96,1 \mathrm{H}, \mathrm{t}, \mathrm{J}=5.0 \mathrm{~Hz}$ & 9- $\alpha, 9-\mathrm{NH}, 11-\mathrm{NH}$ \\
\hline \multirow[t]{5}{*}{$\mathrm{Phe}^{11}$} & $\alpha$ & $4.63,1 \mathrm{H}, \mathrm{dd}, \mathrm{J}=9.5,7.2 \mathrm{~Hz}$ & $10-\alpha, 12-\mathrm{NH}$ \\
\hline & $\beta$ & $2.95,1 \mathrm{H}, \mathrm{dd}, \mathrm{J}=13.2,9.1 \mathrm{~Hz}$ & \\
\hline & & $2.66,1 \mathrm{H}, \mathrm{m}$ & \\
\hline & $\mathrm{NH}$ & $7.21,1 \mathrm{H}, \mathrm{d}, \mathrm{J}=7.2 \mathrm{~Hz}$ & $10-\alpha, 10-\mathrm{NH}, 12-\mathrm{NH}$ \\
\hline & aromatic & $7.26-7.15$ & \\
\hline \multirow[t]{4}{*}{$\mathrm{Phe}^{12}$} & $\alpha$ & $4.27,1 \mathrm{H}, \mathrm{dt}, \mathrm{J}=10.1,6.3 \mathrm{~Hz}$ & 11- $\alpha$, terminal- $\mathrm{NH}_{2}$ \\
\hline & $\beta$ & $\begin{array}{l}2.86,2 \mathrm{H}, \mathrm{dd}, \mathrm{J}=12.9,10.1 \\
\mathrm{~Hz}\end{array}$ & terminal- $\mathrm{NH}_{2}$ \\
\hline & NH & $7.71,1 \mathrm{H}, \mathrm{d}, \mathrm{J}=6.3 \mathrm{~Hz}$ & $11-\alpha, 11-\mathrm{NH}$ \\
\hline & aromatic & $7.26-7.15$ & \\
\hline Terminal- & & $7.11,1 \mathrm{H}, \mathrm{brs}$ & $12-\alpha, 12-\beta, 12-\mathrm{NH}$ \\
\hline $\mathrm{NH}_{2}$ & & $7.12,1 \mathrm{H}, \mathrm{brs}$ & \\
\hline
\end{tabular}




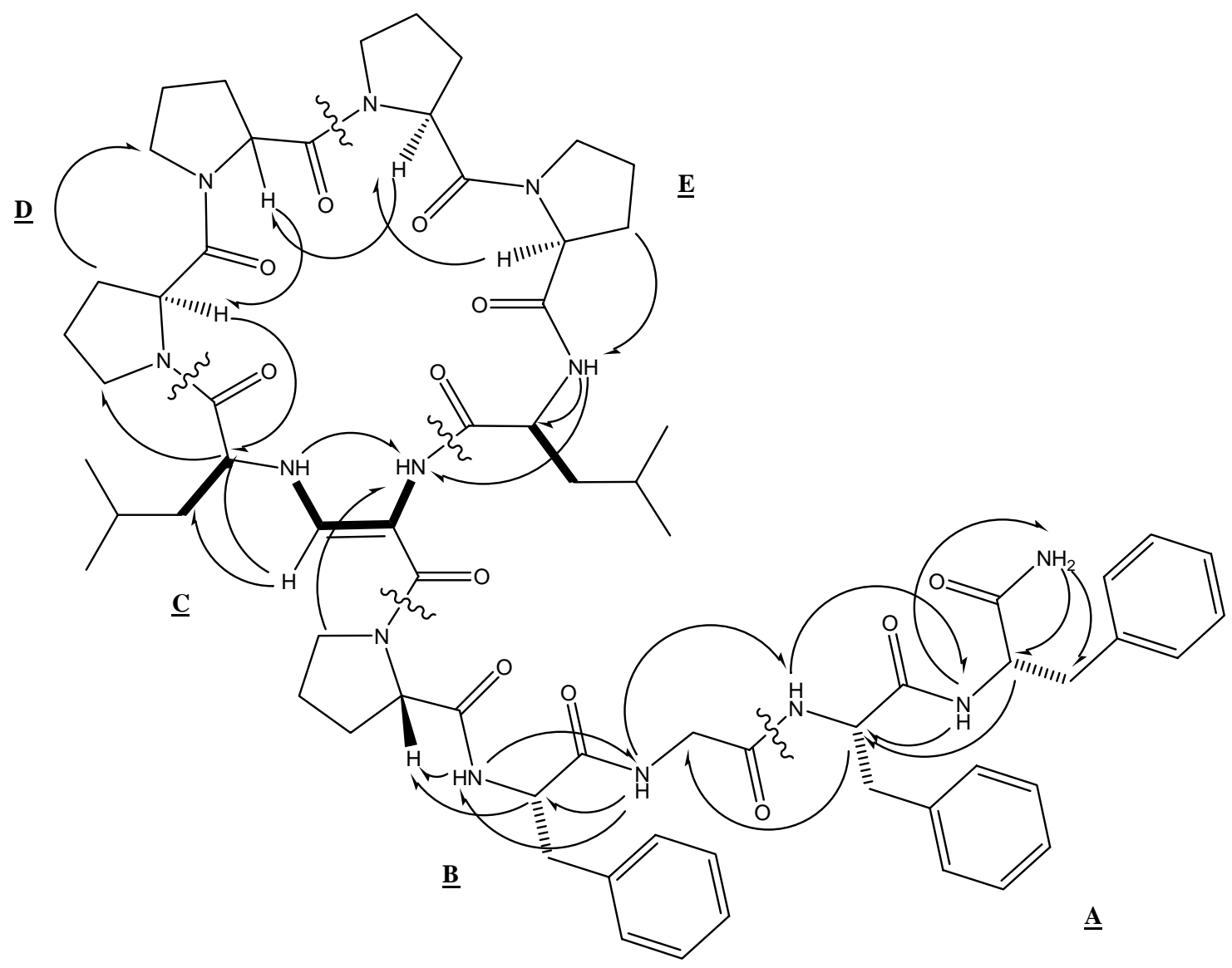

Figure 2. Substructures A-E with ROESY correlations.

\section{Experimental Section}

General Procedures. Melting points were carried out using an Electrothermal 9100 Digital Melting Point apparatus (Electrothermal Engineering Ltd, Essex, England). $\mathrm{MeOH}$ and $\mathrm{CH}_{2} \mathrm{Cl}_{2}$ (1:1) were the crystallization solvents used prior to melting point measurement. The UV spectrum was determined using Perkin Elmer double beam spectrophotometer Model 550S, attached to a Hitachi recorder Model 561, using $1 \mathrm{~cm}$ quartz cell. The IR was measured on a Shimadzu Infrared-400 spectrophotometer (Kyoto, Japan) and the optical rotation was measured on a Perkin-Elmer Model 341 LC Polarimeter (Waltham, Massachusetts, USA). ESI- and LCMS spectra were obtained with a LCQ DECA mass spectrometer (ThermoFinnigan, Bremen, Germany) coupled to an Agilent 1100 HPLC system equipped with a photodiode array detector. FAB-MS was determined using an API 2000 mass spectrometer and HRESIMS was recorded on a LTQ Orbitrap (ThermoFinnigan, Bremen, Germany). Column chromatography was performed using silica gel $60\left(0.04-0.063 \mathrm{~mm}\right.$, Merck), while pre-coated silica gel $60 \mathrm{~F}_{254}$ plates (Merck) were used for TLC analyses. Nuclear magnetic resonance analyses were recorded on Bruker Unity $600 \mathrm{MHz}$ spectrometer using DMSO- $\mathrm{d}_{6}$ as solvent. HPLC separation was performed on a semi-preparative HPLC system consisting of a Lachrom-Merck Hitachi L-7100 pump and a L- 
7400 UV detector using a C-18 column ( $300 \times 8 \mathrm{~mm}$ i.d., prefilled with Eurospher 100, (Knauer, Berlin, Germany), with a flow rate of $5.0 \mathrm{~mL} / \mathrm{min}$.

Animal material. The sponge was collected by scuba diving at depth of 4-5 $\mathrm{m}$ from Ambon, Indonesia in 1996. Freshly collected sponges were frozen immediately after collection and then freeze-dried. A voucher specimen has been deposited in the Zoological Museum, University of Amsterdam, under the registration no. ZMAPOR 17717.

Extraction and isolation. The freeze-dried sponge (300 g) was extracted several times with $\mathrm{MeOH}(2 \mathrm{~L} \times 4)$. The total $\mathrm{MeOH}$ extract was evaporated to dryness $(310 \mathrm{mg})$ and subjected to vacuum liquid chromatography (VLC) over silica gel using hexane, $\mathrm{CH}_{2} \mathrm{Cl}_{2}, \mathrm{EtOAc}$, and $\mathrm{MeOH}$ as solvents. The EtOAc fraction (100 mg) was chromatographed over silica gel column using a $\mathrm{CH}_{2} \mathrm{Cl}_{2}$ : $\mathrm{MeOH}$ gradient and four fractions were obtained. Fraction 3 (26.5 mg) was submitted to semi-preparative HPLC (HPLC gradient program: $60: 40 \mathrm{MeOH} / \mathrm{H}_{2} \mathrm{O}$ from 0 to $5 \mathrm{~min}$. to $100 \%$ $\mathrm{MeOH}$ at $38 \mathrm{~min}$, held until $45 \mathrm{~min}$ with a flow rate of $5.0 \mathrm{~mL} / \mathrm{min})$ to yield callyaerin $\mathrm{G}(6 \mathrm{mg})$.

Callyaerin G. White amorphous powder, $[\alpha]_{\mathrm{D}}-55^{\circ}($ c $0.3, \mathrm{MeOH}), \mathrm{mp} 237^{\circ} \mathrm{C}$. FAB- and $(+)$ ESI-MS m/z (rel. int.\%): $1294[\mathrm{M}+\mathrm{H}]+(36), 1316[\mathrm{M}+\mathrm{Na}]^{+}(100), 682\left[\mathrm{M}-\left(\mathrm{NH}_{2}+\right.\right.$ Phe $12+$ Phe $11+$ Gly $10+$ Phe $9+$ Pro 8)]+ (22), HRESIMS m/z [M+H] 1294.6965 (calcd for $\mathrm{C}_{69} \mathrm{H}_{92} \mathrm{~N}_{13} \mathrm{O}_{12}$ 1294.6983), $1316.6770[\mathrm{M}+\mathrm{Na}]^{+}$(calcd for $\left.\mathrm{C}_{69} \mathrm{H}_{92} \mathrm{~N}_{13} \mathrm{O}_{12} \mathrm{Na} 1316.6802\right)$ ). UV $\lambda \max (\mathrm{MeOH})$ : 207 and $285 \mathrm{~nm}$. IR $\gamma \max (\mathrm{KBr}) \mathrm{cm}-1: 3340,2930,1665,1535,1472,1402,1381$. NMR data (600 MHz, DMSO-d 6 ): see Table 1.

Acid hydrolysis. Callyaerin $\mathrm{G}(1.0 \mathrm{mg})$ was treated with $2 \mathrm{~mL} 6 \mathrm{~N} \mathrm{HCl}$ (p. a.) and heated at $112{ }^{\circ} \mathrm{C}$ for $24 \mathrm{hrs}$ in a sealed ampoule. The solution was concentrated under $\mathrm{N} 2$ gas to dryness, with three consecutive additions of $\mathrm{H}_{2} \mathrm{O}(5 \mathrm{~mL}$ each $)$ to ensure complete elimination of $\mathrm{HCl}$.

Marfey derivatization and LC-MS analysis. ${ }^{8 \mathrm{a}}$ To $40 \mu \mathrm{L}$ of the acid hydrolysate (or authentic amino acid standard at comparable concentration), $80 \mu \mathrm{L}$ FDNPL (1\% N-(5-fluoro-2,4dinitrophenyl)-L-leucinamide in acetone) and $20 \mu \mathrm{L} 1 \mathrm{M} \mathrm{NaHCO}_{3}$ were added. The mixture was heated over a hot plate at $40{ }^{\circ} \mathrm{C}$ for $1 \mathrm{hr}$ with frequent mixing. After cooling, $20 \mu \mathrm{L}$ of $2 \mathrm{M} \mathrm{HCl}$ was added and the volume was diluted to $1000 \mu \mathrm{L}$ with $\mathrm{MeOH}$. L and D amino acid standards were treated separately with FDNPL in the same manner. The FDNPL derivatives were analyzed by LC-MS through comparison of the retention time and molecular weight with those of standard amino acids FDNPL derivatives.

Cytotoxicity study. ${ }^{11}$ The cytotoxicity of the isolated peptide was tested in vitro against mouse lymphoma (L5178Y), human cervix carcinoma (Hela), and rat brain tumour (PC12) cell lines using the microculture tetrazolium (MTT) assay at concentrations of 3 and $10 \mu \mathrm{g} / \mathrm{mL}$. 


\section{Acknowledgements}

We are indebted to Prof. Dr. W. E. G. Müller (Institute für Physiologische Chemie, Duesbergweg 6, D-55099 Mainz, Germany) for cytotoxicity testing.

\section{References}

1. Nakao, Y.; Uehara, T.; Matsunaga, S.; Fusetani, N.; Van Soest, R. W. M. J. Nat. Prod. 2002, 65, 922.

2. Youssef, D. T. A.; Fusetani, N.; van Soest, R.W. J. Nat. Prod. 2003, 66, 861.

3. Braekman, J. C.; Daloze, D.; Devijver, C.; Dubut, D.; Van Soest, R. W. M. J. Nat. Prod. 2003, 66, 871.

4. Youssef, D. T. A.; Van Soest, R. W. M.; Fusetani, N. J. Nat. Prod. 2003, 66, 679.

5. Rooney. F.; Capon, R. J. Lipids 1998, 33, 639.

6. Capon, J. R.; Ford, J.; Lacey, E.; Gill, J. H.; Heiland, K.; Friedel. T. J. Nat. Prod. 2002, 65, 358.

7. Berer, N.; Rudi, A.; Golgberg, I.; Benayahu, Y.; Kashman, Y. Org. Lett. 2004, 6, 2543.

8. (a) Teuscher, F. Ph.D. thesis, Düsseldorf, Germany 2004. (b) Ibrahim, S. R. M. Ph.D. thesis, Düsseldorf, Germany 2005.

9. Svete, J.; Aljaz-Rozic, M.; Stanovnik, B. J. Heterocycl. Chem. 1997, 34, 177.

10. Marfey, P. Carlsberg Res. Comm. 1984, 49, 586.

11. Edrada, R.; Proksch, P.; Wray, V.; Witte, L.; Müller, W. E. G.; van Soest, R.W.M. J. Nat. Prod. 1996, 59, 1056. 